\title{
CLAREAMENTO INTERNO EM DENTES NÃO VITAIS - UMA ALTERNATIVA A TRATAMENTOS RESTAURADORES INVASIVOS: RELATO DE CASO
}

Elise Alves de MIRANDA, Helena Laskawski KLEMBA, João Luiz Neves PEREIRA

O clareamento dental é um tratamento cosmético muito solicitado nos consultórios odontológicos devido ao apelo estético por dentes brancos e bem alinhados. Em dentes não vitais com alteração de cor, o clareamento interno é indicado por ser um procedimento relativamente simples, de baixo custo e eficiente a longo prazo. No entanto, podem ocorrer efeitos deletérios para os dentes e suas estruturas de suporte, com a reabsorção cervical externa sendo a mais grave descrita na literatura. Este relato pretende descrever o caso de um paciente de 27 anos, sexo masculino, que procurou a Universidade Federal do Paraná com queixa estética no dente 23. Durante o exame clínico e radiográfico observou-se que o dente apresentava pigmentação amarronzada, de cervical para incisal e tratamento endodôntico satisfatório. A conduta clínica consistiu na associação das técnicas de demora (mediata) e termocatalítica (imediata). Após três sessões, o dente atingiu uma coloração satisfatória e compatível com as expectativas do paciente. A partir deste resultado pode-se observar que o clareamento interno é uma opção conservadora, pois evita 0 desgaste da estrutura dental quando comparado à tratamentos protéticos invasivos.

Palavras-chave: Clareamento dental; Dentística; Estética Dentária. 